\title{
Public Policy for Private Higher Education in China
}

\author{
Huijuan Lin \\ School of Accounting and Finance \\ Beijing Institute of Technology Zhuhai campus \\ Zhuhai, China \\ Taro_930@126.com
}

\begin{abstract}
The paper aims to analyze the underlying public policies under the circumstances and this analysis is a prerequisite to the further development of private education in China. This paper first set out to analysis characteristics of private higher education in China. And then, by reviewing the relevant historical and documentary literature, analysis and discussion will be carried out to illustrate how government supports the growth of private higher education by policies in China. After the analysis and discussion of the policies, some of the limitation and barriers during the implementation of the policies will be illustrated. In addition, role of governments in China and other countries will be comprised and analyzed on how to make the development of private higher education on a healthy and sustainable track for the long-term. Finally, the conclusion will give suggestions on how public policies should be in higher education system.
\end{abstract}

Keywords-private higher education; public policies; governance

\section{INTRODUCTION}

Many countries have seen the incredible increases in the fast development of private education providers in the last decades. This is due to the student enrollment expansion. Without any doubt, China has seen this phenomenon as well though it had a powerful public higher education system historically. More than 740 private education providers, which accounts for $28.59 \%$ of all the higher education institutions (HEIs) in whole China, were able to grant diplomas and degrees in the year of 2016. Further, according to the Ministry of Education [7], 813 private education providers provide services to self-study students preparing for higher education exams. Inspired by one pluralist project which aims to introduce the social and market actors into the current state supervisory model, private HEIs reemerged in China, although it is a huge contradiction to the state-control model in the perspective of this pluralist model [6]. After reform of higher education in China, it is required to have a thorough understanding of the importance to keep a suitable balance between the development of private higher education providers and the governmental control of the education system. Therefore, the essay aims to analyze the underlying public policies under the circumstances and this analysis is a prerequisite to the further development of private education in China.

\section{Objectives of Public Policies on Private Higher EDUCATION}

The various private higher education providers are essential to the realization of public education objectives. They are not the objectives themselves. For the promotion of private higher education in China, the critical point is to expand the private higher education forms and integrate the public and the private into an efficient education system. Therefore, the huge demand for better education schooling in China could be more satisfied to meet. Policies regarding private education shall encourage the private education to supersede the constraints of education ownership and to be integrated into the development of society. If not, there will be chaos between these different types of education institutions and it is likely to lead to inequitable education policies. .

The private education-related policies issued by the Chinese government might mainly aim to promote the development of school-operating resources and improve the related effectiveness. Rather, it does not mean that other aims could be totally neglected. Except from meeting the goal of providing sufficient public education funds, policy makers shall bean in mind that for the promotion of private education in China, the education quality shall play an essential role as well. Under the current circumstances, it is nearly impossible to come up with ideal operating standards. However, it shall be bear in mind that private education providers operate above a basic standard. Government shall cooperate with private education providers and these institutions' performances shall be publicized by government. For the private education institutions that perform positive, spiritual or material rewards shall be given. And for the negative ones which perform badly, they shall receive assistance or punishment. Obviously, large considerations have been given to the private institutions' property rights and interests when it comes to the private education policies. However, little concerns have been raised about the students who are receiving the education. It shall be pointed out that the schools' institutions should not be the objective of education policies. Rather, students who are studying in the institutions should be the objective. Compared with the interests of educational institutions, the students' interests matter more due to the fact that students are the primary concern of the government and institutions only takes the second place. When a public or private school fail to operate again, the first concern that shall be solved out is that these students shall be taken good care of and their rights to continue studying should be guaranteed. If the government wants to offer funding subsidies the private education system, the teachers and students should be the objective of such subsidies. Private education policies are largely influenced by the people who are receiving private education. Certainly, private schools are free to determine their school operations. And they are not necessarily asked to set their school-running objectives in a perfect conformity with the development of society. Due to the fact that private schools and society do not share the same goals or objectives, it is very necessary for the government to encourage or ban private 
schools' behavior effectively. Thus, distinct schools might clearly realize that the real need of society and adjust their operating objective under the influences of government and market. It is strengthened that the government needs to play a positive role in reduce differences in society and pay special attention to poor students. On the basis of investigation and research, the government is obligated to carry out educational finance actions to those poor students and effectively narrow the gap between rich and poor by targeting different people with different finance conditions.

\section{Limitations AND BARRIERS OF CURRENT PubliC POLICIES}

The policy choices of the development of higher education in China have gained many conflicts. These conflicts are not merely the value paradoxes to promote private higher education. They are also the source that leads to other conflicts. As the above mentioned analysis shows, the conflicts originated from the rapid development of private and mass higher education have also been clearly displayed in the process of making policies and the implementation of these policies, just like the situation that the development of higher education of China has experienced. Indeed, it will be beneficial to the colleges and universities as well as the government to improve the policy-making standards and the implementation of policies and to develop higher Studies in Higher Education in China healthily, if these contradictions are envisaged and the trends of the development of higher education are grasped and being seriously considered.

\section{A. Scale and Quality}

The relationship between scale and quality, just like the famous metaphor of fish and paw of bear, is considered by many that they could not be obtained at the same time. Conflicts appeared when trying to pursue these two objectives simultaneously [12]. Since the last two decades in China, it has been difficult to make policies for higher education development when trying to select the scale-out policy or quality-oriented policy. Under the current conditions, the conflicts between these two policies are even more antagonistic and realistic. What's more, in recent years, the number of participants taking the college entrance exams has begun to decrease. At the same time, the enrollment rate keeps a relative high level and thus the government and universities are both encouraged paying more attention to the quality of higher education and choose to stabilize the scale. On the other hand, what could not be ignored is that under the current situation, the gross enrollment ratio is still low. This means that only minority of college-age students are able to go on their study in higher education institutions and the majority of those young people have lost their way to pursue higher education in China. Compared with the western countries, China still has a quite low rate of citizens attending higher education. The major proportion of students attending colleges and universities are still the traditional students. Those working in the factory or in the office are hard to attend such institutions due to the lack of appropriate measures supported by both the government and the industry itself. These people are only able to attend higher education theoretically or legally. On the other hand, it could not be neglected because the demands of these people to enjoy higher education services are high and important. As a matter of fact, in the process of higher education development in China, there has been a huge pressure from the scale policy.

\section{B. Values of Utilitarian and Non-Utilitarian}

Since the appearance of modern universities in the world, the paradox between the values of utilitarian and non-utilitarian has affected the development of higher education. Due to the effect of traditional pragmatic philosophy in China, the utilitarian values of higher education have been strongly propagated and accepted in the higher education system in China. However, the non-utilitarian values just appeared in the late 20th century in China. With the rapid development of China since the famous reform and opening-up policy put into practice, more people are trying to emphasize the importance of multiple values, among which the non-utilitarian values gained much attention, in universities and colleges. The highlight of non-utilitarian values shocked the superiority of utilitarian values and inspired more scholars to rethink the development of higher education in China. Therefore, when it comes to making policies to develop higher education in China, it is quite essential to keep a balance between the utilitarian values and the non-utilitarian values. In fact, the basic principles of cultivating students foremost has been successfully formed, which includes directions of underlining the cares for each student, urging every student's active and brisk development, following the rules of education itself to develop higher education rather than the rules of market and economy, adhering the nature of human beings to cultivate students' body and mind, providing proper education for individual one and developing individuality of each one. However, the utilitarian values have been the dominating orientation of value selections in the policy of higher education development under the background of educational, economic and political traditions, especially, in the context of fierce competition among institutions of higher education for inadequate resources. Since institutions of higher education are mainly established and run by the provincial governments as well as the central government in China, and the governments have taken economic development as their working focus, thus serving economic development has become the most important direction of colleges and universities under the leadership of centralization of higher education administration. Though the Government has not just cared about the relationship between higher education and economic development, and colleges and universities have been driven to educate students completely and individually, the utilitarian function of higher education has been given more attention in the operation of colleges and universities.

\section{Localization and Internationalization}

Without any doubt, internationalization is one of the most important characteristics of higher education across the globe. As for localization, it is considered as the cornerstone for a country's higher education system. Yet, these two distinct features are complementary to each other under the current situation. In the late 19th century, China introduced modern higher education from the western world. And since then, conflicts between nationalization/ internationalization and 
localization constantly appeared. It was then typically described in the policy choice of education as 'western learning for practical applications, while Chinese learning as the basis.' The conflict accompanied the higher education in China for no less than one century. Until now, this conflict still exists and plays a role in deciding the policy choices for higher education development. It has been nearly 40 years since the implementation of the famous opening-up policy, which opens the door for China to see the outside world, many international elements of higher education have significantly influenced the higher education in China. For instance, Chinese universities and colleges have established a good partnership with foreign higher education institutions, many foreign scholars have been attracted and recruited by Chinese universities and teach students in class, and a lot of joint educational programmes have been adopted and successfully completed among foreign universities and Chinese universities. Thus, internationalization represents one of the feature of Chinese higher. Apart from this, it also is an essential trend of higher education development in China. Even so, worries and criticisms still exist and opponents show concerns about the internationalization of Chinese higher education. Many opponents worry that so-called internationalization may cause our own higher education become westernization and loses our own features and become some other country's style of higher education. Thus, many people concern that when promoting the internationalization of Chinese higher education, of great importance shall be paid to the real value of localization in this process. Nonetheless, the traditional view towards the relationship between internationalization and localization has changed. A lot of distinct voices appeared in the current, with the purpose of localization that has been mainly laid on cultivating Chinese characteristics of higher education and that of internationalization has been referred to comprehensive docking with the outside.

\section{ROLE OF GOVERNMENT}

According to Dobbins [3], in university systems, there are several possibilities that are suggested to achieve balance between institutions when it comes to the conceptual elements of $\mathrm{HE}$ governance. For instance, there are 4 types of universities by some certain standard [10]. First, regardless of political convenience, economic benefit, immediate utility, and applicability, universities are considered as scholar communities, which are founded on a self-defined and academic oriented organizational identity. Second, from the perspective of national purpose, universities can be regarded as instruments for this special aim. Thus, when it comes to deciding a university's development direction, the key considerations are practical problem-solving researches rather than scholarly purpose. Third, universities can be regarded as classic democracies which emphasize the link between democratization on university campus and in society. Finally, form the perspective of markets, universities are like service enterprises more or less. This perspective of universities suggests that higher education is sold in the free market as a commodity. And the key considerations that decide the development direction of one university are survival and competitiveness. The four different definitions of universities constitute distinct conditions. Under these circumstances, the relationship between state, university, and society are defined and quality control management, personnel management, financial arrangement, and structure of decision-making are expanded. In a similar way, to capture the characteristics of higher education governance, some scholars raise three distinct models such as the state-centred model, the market-oriented model and the Humboldt model [3]. In details, the state-centred model assumes that when it comes to the development of a university, the state is the most important factor that matters. The market-oriented model, however, suggests that for a university, it operates as a business company both in local and global markets, and entrepreneurialism is the most important organizational principle. As for the Humboldt model, it emphasizes the significance of the nature of a university as a scholar-self-governing community. Under this circumstance, academic oligarchy or academic self-governance is considered as the organizational principle of a university. Further, to illustrate the diversification of current HE governance, another two concepts which overlap with the above-mentioned models are raised. The first one is called shared governance, which emphasizes that in HE governance, governing boards and councils are filled with more and more lay members. For this shared governance model, an important feature that matters is the introduction of a bicameral system. This system consists of two parts, one is the academic body or the senate, and another is lay-dominated governing body or the council. These two parts both share statutory authorities when it comes to the big issues of a university. To achieve the aim of separation among power, checks and balances, it is not unnecessary to maintain a healthy degree of balance between the two bodies [13]. In a larger picture, the principles are essential for they uphold public accountability when it comes to the adoption of New Public Management (NPM) in higher education. The next concept refers to corporate governance which assumes that a university is an entrepreneurial organization. The nature of entrepreneurship is emphasized by the fact that when it comes to competing in the HE market and acquiring industrial capitals, universities tend to be more proactive. Thus, their responsiveness to the needs of customers and the whole industry increased [2]. The entrepreneurialism concept indicates that for the future development of a university, it needs to be more active in creative industries. And it is encouraged to keep a close relationship between the university itself and the industry or the market.

For the purpose of tracing changes in policy comparatively, three governance models are distinguished and the case in China is analyzed [1]; [10]; [3]). In the view of state-centered model, limited autonomy is given to universities as they are state-run higher education institutions. As Clark [1] has pointed out, in the state-centered model the market and the 'academic oligarchy' have limited roles to play. According to Neave and Van Vught [7], the state plays a role just like a 'guardian' and, essentially, it has a huge impact on the internal matters of a university such as admissions, funding, curricula, quality management and the relationship between university and industry. Olsen [10] points out that the reason the state engages in the control of universities is to make sure that national priorities are met by universities. In China, the government offers financial funding to the public universities. And the findings given to these public universities are linked to budget 
and staff rather than the number of students. Though the state has the right to decide planning and funding of a university, the teaching and research of a university is decided by itself. Jongbloed [5] points out that governments offer itemized funding, and universities are limited to monetary discretion. To ensure the quality assurance, the ex-ante plausibility that universities capable of carrying out programmes are taken into consideration. In China, all the public universities are state-run and the state-centered model depicts their true nature. With the social, political and economic issues becoming increasingly complicated, the effectiveness and satisfactory utilization of the old approach to solve out them is questioned by many. To deal with the pressures of rapid development of globalization and to keep competitiveness of a nation, new governance philosophies and governance forms are emerging. Faulks [4] note that in public management and policy instruments, fundamental transformations have already taken place. According to Pierre [11], 'new governance' theories suggest that the government needs to change its role in universities and to employ new governance forms that are based on society and focuses on 'self-governance and co-ordination '. In spite of this, Chinese HE system has experienced reform. The development of independent universities and some of private universities or socalled minban in Chinese is fast. 'Marketization' is the significant character that labels the current reforms (Olsen, 2007)[10]. This refers to that university management is strengthened and economic utility of knowledge shall be focused on by universities. Based on Clark [2], the marketcentred model hypothesizes that when operates as an economic enterprise, the university functions more effectively. Thus, private HE institutions are regarded as the product of entrepreneurial institutional leadership rather than state design. Ideas that based on private enterprise such as performancebased funding and NPM [11] purportedly promote rapid adaptations to many new opportunities. High level of autonomy ensures that the university could define programmes strategically and make suitable admission conditions and recruit professional staff. On the other hand, this does not mean that the state retreats. Rather, the state plays its role as an 'evaluator' via quasi-governmental quality assurance bodies ([9]; [10]). Except from funding, normally, the state supports the development of public universities with other resources. However, the budgetary discretion makes the universities depend on tuition and investment. With the rapid development of private sectors in China, the relationship between state and society has become increasingly complicated. This complicated relationship is even more obvious when taken the current role of government as coordination and steering rather than command.

\section{Conclusion}

Though it is now a major trend to choose the decentralization in the making of polices for higher education development in most nations, it does not mean that the effect of centralization on the development of universities could be neglected, especially in centralized countries like China. Since the year of 1985, when the Chinese government determined to decentralize the administration power of higher education with the promulgation of the momentous document 'Decision on Reform of Education System', the central government has been making efforts to authorize some of the administration power to provincial governments. Furthermore, for the universities and colleges in China, there were given autonomy to some extent. As one of the most centralized countries in the world, the Chinese central government still retains its administrative power regarding some of the critical management issues of higher education institutions such as making the guiding policies and the absolute leadership over provincial authorities. By employing the reforms of such decentralization policies, the central government's role is shifting from micro-management to macro-management of higher education development. From a perspective of provincial governments, their authorized power has been expanded to approving and managing institutions and colleges of higher vocational education as well as coordination within the scope of their authorization under the general policies issued by the central government. As one of the most important results of such reforms, now both the private and the public higher education institutions are able to enjoy more autonomy and to self-determine their development directions. Although 'decentralization' is the key word for the reform of higher education in China today, the absolute leadership and supreme power of central government over provincial authorities and HEIs indicates that centralization still prevails decentralization in the higher education management system at the current stage. The balance will continue to change and will be influenced by the Chinese politic system.

\section{REFERENCES}

[1] Clark B.R., The higher education system: academic organization in cross-national perspective. Berkeley: University of California Press, 1983.

[2] Clark B, Creating Entrepreneurial Universities: Organizational Pathways of Transformation. Oxford: Pergamon, 1998.

[3] Dobbins, M., Knill, C., and Vogtle, E.M., An analytical framework for the cross-country comparison of higher education governance. Higher Education, 62 (5), 665-683. doi:10.1007/s10734-011-9412-4, 2011.

[4] Faulks, K., Political sociology: a critical introduction (NY, New York University Press), 2000.

[5] Jongbloed B, Institutional funding and institutional change. In: File J and Goedegebuure L (eds) Real-time Systems. Enschede: Logo CHEPS, pp. 115-146, 2003.

[6] Levy, D. C., The unanticipated explosion: Private higher education's global surge. Comparative Education Review, 50(2), 217-240, 2006.

[7] Ministry of Education of the People's Republic of China, "2016 National Educational Development Statistics Bulletin,” http://www.moe.edu.cn/jyb_sjzl/sjzl_fztjgb/201707/t20170710_309042. html, July 10, 2017.

[8] Neave G and Van Vught F, Prometheus Bound: The Changing Relationship between Government and Higher Education in Western Europe. Oxford: Pergamon, 1991.

[9] Neave G, The evaluative state reconsidered. European Journal of Education 33(3):265-284, 1998.

[10] Olsen, J., The institutional dynamics of the European university. In: M. Peter and O. Johan, 2007.

[11] Pierre, J. (Ed.), Debating governance (Oxford, Oxford University Press), 2000.

[12] Pan, Mao-yuan, "Equity and Efficiency: The Bases of Higher Educational Policy Making.” Peking University Education Review 1 (1): 54-57, 2003.

[13] Taylor, M., Shared governance in the modern university. Higher Education Quarterly, 67 (1), 80-94. doi:10.1111/hequ. 2013. 67. issue-1, 2013 